\title{
Analysis of The Effect of Price, Promotion, Trust, Service Quality on Consumer Loyalty in Use of Shopee Online Store
}

\author{
Mutiara Lusiana Annisa ${ }^{1}$

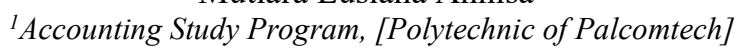

\begin{abstract}
The purpose of this study was to analyze the influence of price, promotion, trust, and service quality on consumer loyalty in using Shopee online store. The population of the study was students in 12 private higher education institutions. This study used purposive accidental sampling. This study used multiple regression analysis. The results of study showed that price, promotion, trust, and service quality simultaneously and significantly influenced consumer loyalty in using Shopee online store. Partially, price significantly influenced consumer loyalty, promotion significantly influence consumer loyalty, trust significantly influenced consumer loyalty, and service quality significantly influenced consumer loyalty in using Shopee online store.
\end{abstract}

Keywords: Price, Promotion, Trust, Service Quality, Online Store

\section{Introduction}

The increasingly fierce business competition causes many companies to think more creatively and innovatively in responding to changes that occur in all fields of social, political, economic, and cultural fields. The changes that occur require the company to increase economic profits and retain customers in order to achieve company goals. Therefore, the company must have a strategy to increase profits and retain loyal customers by developing technology that is easily accessible to the public in order to meet the wants and needs of goods or services. The availability of goods and services provided by the company by developing easier access will help consumers meet their needs and the company will get increased profits.

The strategy of the company in increasing profits can be performed in various ways both by utilizing the media both offline and online media. In the business world, online media is often used to increase profits by offering a variety of products using online marketing media or through digital marketing by presenting interesting content in terms of the strength of the product. By offering products through digital marketing media, it is hoped that the company will get more profits in promoting the product. Based on the description above, the price offered, consumer trust, service quality provided by the Shopee marketplace, and promotion strategies by the Shopee marketplace will certainly have a special attraction for researchers to determine the level of loyalty in the Shopee marketplace.

Shopee is an online marketplace where there are buying and selling transactions using online media easily and quickly. Shopee offers consumers a variety of products to meet consumer needs. Shopee has mobile applications and websites for buying and selling transactions with smartphone media or via a PC to make it easier for consumers to access information related to their needs. Shopee Indonesia is a marketplace owned by Garena 
(renamed SEA Group) in Singapore. The C2C business that has been managed by Shopee has been accepted by the people of Indonesia. Shopee Indonesia has been officially in Indonesia since December 2015 under PT. Shopee Internasional Indonesia. Since its launch, Shopee has grown very rapidly as evidenced by October 2017, the application has been downloaded more than 43 million users. At this time, the Shopee application in Indonesia has introduced consumers to a new shopping experience and has provided facilities that facilitate buyers with a secure payment process and provide integrated logistics services. In addition, Shopee is also committed to developing an entrepreneurial spirit for sellers. Sellers are empowered to become more effective sellers by providing access to millions of consumers at no cost and better managing the availability of goods and customer relationships.

One factor that indicates the level of consumer loyalty is the price. Price is a factor that must be considered by the company. According to [4] price is part of the marketing element that generates revenue where other elements require costs. Meanwhile, according to [1], based on the theory of economy, price is value and utility which are part of the relevant concept. In determining the price of a product, a company must pay attention to various parties such as consumers, competitors, investors, employees, suppliers of goods, and government. Pricing is inseparable from the ability of consumers to buy goods or services or in other words consumer purchasing power, the reaction of competitors, types of products, the elasticity of demand, and company profits. Besides price, another factor that must be considered is promotion. Promotion is one of the strategies carried out by the company in increasing company revenue. Promotion is not only useful as a communication tool between companies and consumers but as a tool that can influence customers in purchasing activities in accordance with the wants and needs of consumers. Likewise with the trust which is part of the factors that influence consumer loyalty. The indicator to determine trust is the suitability between desire and performance that will create a positive impression to continue to use products offered through online shops that are believed by consumers. Based on the background that has been described, the author is interested in making a study entitled "The Influence of Price, Promotion, Trust, Service Quality on Consumer Loyalty in Using Shopee Online Store".

\subsection{Signaling Theory}

Signaling theory discusses the desire of companies to provide information to external parties. This desire is due to the asymmetry of information between management and external parties. Signaling theory shows that there is an asymmetrical relationship between management and stakeholders on the information of the company [5]. Information asymmetry occurs because one party has better information than the other party. Management as an internal party of the company has better information compared to external parties. Before deciding to buy, the company should provide information in accordance with the wants and needs of consumers. Information that fits the wants and needs of consumers will determine consumer loyalty to repurchase a product offered by the company.

\subsection{Price}

According to [5], price is the amount of money determined by the company for a product that consumers must pay. The money paid by consumers will be used by the company to cover production costs and non-production costs. Based on the point of view of the consumer, price becomes the determinant that must be considered by the company because price represents the benefits felt by the consumer. The higher the price, the less the perceived benefits by consumers while the lower the price the perceived benefits will be even greater. Thus, price is an indicator that influences consumer loyalty in using online stores. 


\subsection{Promotion}

According to [9], promotion is a form of direct persuasion by using incentives to stimulate consumers to buy a product offered by the company or increase the number of customers who will buy a product. The more attractive promotion is, the more it will affect the interest to repurchase a product offered by the company. Thus, promotion price is an indicator that influences consumer loyalty in using online stores.

\subsection{Trust}

Trust is an important indicator in determining interest in repurchasing or consumer loyalty for a product offered by a company online. According to [3], the complexity and diversity of online interactions through social media are an important part of building trust. The higher the level of trust in a product offered by the company using social media, the more sales will increase. So that trust becomes a factor that needs to be considered in measuring consumer loyalty in using online stores.

\subsection{Service Quality}

According to [9], service quality is the expected strength and control over the strength to meet consumer desires. Service quality can provide a strong desire for customers to form a good relationship with the company (Kotler and Keller, 2016). The better the service of a company, the more consumer loyalty will increase.

\subsection{Consumer Loyalty}

According to [10], consumer loyalty is a customer commitment to a product used by consumers arising from trust and a high positive impression that encourages consumers to remain subscribed to the company. The existence of a match between desires and performance will create satisfaction. The desire and performance that are in line will create a desire to continue to use a product in a business entity.

\subsection{Online Store}

The online store is electronic commerce that trades goods through internet media (online). Electronic commerce (E-Commerce) not only sells goods but also services such as e-banking to facilitate consumers to make the transfer process to pay electricity bills, water, college needs, and others. The development of e-commerce through online shops in Indonesia has been growing rapidly. This is marked by the number of online shop sites in Indonesia ranging from clothing boutiques, automotive equipment, fashion, food, and more. E-commerce sites in Indonesia are experiencing rapid development in the process of buying and selling activities, this can be categorized based on existing business models in business entities. The ecommerce categorization includes the $\mathrm{C} 2 \mathrm{C}$ Marketplace, Shopping malls, B2C online stores, and online stores on social media.

\section{Methodology}

\subsection{Hypotheses}

Based on literature review and previous studies, the hypotheses are as follows:

H1: Price significantly influences consumer loyalty in using Shopee online store

H2: Promotion significantly influences consumer loyalty in using Shopee online store 
H3: Trust significantly influences consumer loyalty in using Shopee online store

H4: Service Quality significantly influences consumer loyalty in using Shopee online store

\subsection{Framework}

The study model is illustrated in the following figure:

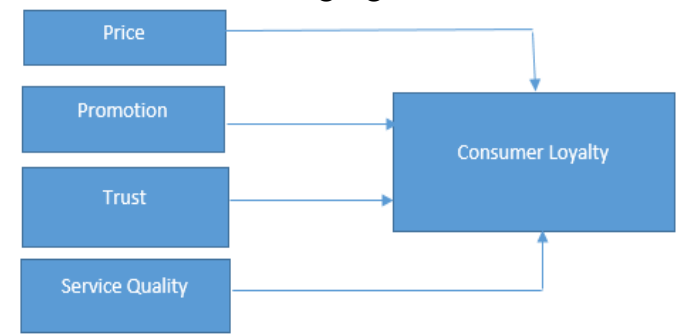

Fig.1. Framework

\subsection{Population and Sample}

The population of this study was private higher education students in Palembang City as users of Shopee online store. The population was determined based on 12 private higher education institutions with the highest number of students in Palembang City. Objects of this study were Bina Darma University, IBA University of Palembang, Tridinanti University, PGRI University of Palembang, Kader Bangsa University of Palembang, Palembang University, Muhammadiyah University of Palembang, Indo Global Mandiri University, STMIK PalComTech, PalComTech Polytechnic, Akamigas Polytechnic of Palembang, and STISIPOL Candradimuka. The number of students was obtained from the forlab.ristekdikti.go.id. This study used a random sampling technique without regard to strata in the population. The number of samples collected was 270 samples.

\subsection{Data Analysis Method}

This study used multiple regression analysis. According to Sugiyono (2014), multiple regression analysis functions to determine the state of the dependent variable if there are two or more independent variables as a predictor factor. The independent variables in this study were Price, Promotion, Trust, and Service Quality while the dependent variable was Consumer Loyalty. The regression equation in the multiple regression analysis method is as follows :

$$
\mathrm{Y}=\alpha+\mathrm{b}_{1} \mathrm{X}_{1}+\mathrm{b}_{2} \mathrm{X}_{2}+\mathrm{b}_{3} \mathrm{X}_{3}+\mathrm{b}_{4} \mathrm{X}_{4} \epsilon
$$

\section{Result and Discussion}

\subsection{Descriptive Statistics}

Descriptive statistics (Sugiyono, 2007) functions to provide information relating to data collection and presentation of data in a descriptive manner or to provide a description of an object being examined through population or sample data. the price variable had a mean of 39.48 and a standard deviation of 2.843 . While the promotion variable had a mean of 44.05 and standard deviation of 2.626. Trust variable had a mean of 44.44 and standard deviation of 3.447. Service quality variable had a mean of 17.62 and standard deviation of 1.382 . Based on the results of descriptive statistics on the four independent variables, the mean value was higher than standard deviation. This shows that there was no gap in a variable. 


\subsection{Hypothesis Test}

\subsubsection{Coefficient of Determination}

The coefficient of determination is part of the hypothesis test that shows the contribution of the independent variable to the dependent variable. The results of the study show that the Rvalue was 0.664 or $66.40 \%$, this shows that Price, Promotion, Trust, and Service Quality variables simultaneously influenced $66.40 \%$ while the remaining $33.60 \%$ was influenced by other factors. The coefficient of determination shows the magnitude of the influence of Price, Promotion, Trust, and Service Quality variables of $44.10 \%$ and the remaining $55.60 \%$ was influenced by other factors outside the study model.

\subsubsection{Simultaneous Test (F Test)}

Simultaneous Test (F Test) is part of hypothesis testing by looking at the effect of independent variables on the dependent variable simultaneously. Here are the results of simultaneous test of independent variable on the dependent variable or F-test :

Table.1. Results of Simultaneous Test

\begin{tabular}{|c|c|c|c|c|c|}
\hline \multicolumn{6}{|c|}{ ANOVA $^{\mathrm{a}}$} \\
\hline Model & & Sum of Squares & df & Mean Square & Sig. \\
\hline 1 & Regression & 226.342 & 4 & 56.586 & $52.225 .000^{\mathrm{b}}$ \\
\hline & Residual & 287.125 & 265 & 1.083 & \\
\hline & Total & 513.467 & 269 & & \\
\hline
\end{tabular}

The F-test value obtained was 53,225 with a significance value of F-calculated of 0,000 . To determine the influence of the independent variable on the dependent variable is by looking at the significance value at F-calculated of 0,000 compared to the significance value at F-calculated of lower than 0.05 so it can be concluded that Price, Promotion, Trust, and Service Quality variables simultaneously influenced Consumer Loyalty.

\subsubsection{Partial Test}

The results of the partial test of the independent variable on the dependent variable or Ttest, price variable had a significance value of 0.01 , promotion variable had a significance value of 0,000 , trust variable had a significance value of 0.002 , then service quality variable had a significance value of 0.003 . Partial test is carried out by measuring the significance value at $t$ calculated lower than 0.05 so that when viewed per variable the significance value is below 0.05 , so it can be concluded that price variable significantly influenced consumer loyalty, promotion variable significantly influenced consumer loyalty, trust variable significantly influenced consumer loyalty, and service quality variable significantly influenced consumer loyalty in using online store shopee.

\subsection{Discussion}

\subsubsection{The Influence of Price on Consumer Loyalty}

The results of hypothesis testing of price variable on consumer loyalty in using Shopee online store showed that that price variable significantly influenced consumer loyalty in using Shopee online store. This is indicated from the results of the partial test where the significance value of the $\mathrm{t}$-calculated was smaller than 0.05 . While the second alternative was by comparing $\mathrm{t}$-calculated with $\mathrm{t}$-table where $\mathrm{t}$-calculated of price variable was 3.339 compared to 
t-table of 1.968956 . If $t$-calculated was greater than t-table then price variable significantly influenced consumer loyalty in using Shopee online store. In pricing, online shopping using Shopee provides benefits to Shopee users because they can bargain. Consumers can get goods at fairly cheap prices. In addition, Shopee also offers 8 shipping services to choose from and can also send goods from abroad. In addition, each shipping service offers a different price, so consumers can choose according to their budget.

\subsubsection{The Influence of Promotion on Consumer Loyalty}

The results of hypothesis testing of promotion variable on consumer loyalty in using Shopee online store showed that that promotion variable significantly influenced consumer loyalty in using Shopee online store. This is indicated from the results of the partial test where the significance value of the $t$-calculated was smaller than 0.05 . While the second alternative was by comparing $t$-calculated with $t$-table where $t$-calculated of promotion variable was 3.623 compared to $\mathrm{t}$-table of 1.968956 . If $\mathrm{t}$-calculated was greater than $\mathrm{t}$-table then promotion variable significantly influenced consumer loyalty in using Shopee online store. Promotions offered by Shopee also vary from cashback to 100 thousand rupiahs, $90 \%$ discount, and others. Shopee offers promotions almost every day. The more consumers spend, the more promotions they get. Promotions offered by Shopee get a good response from consumers this results in consumer loyalty to shop using Shopee online store.

\subsubsection{The Influence of Trust on Consumer Loyalty}

The results of hypothesis testing of trust variable on consumer loyalty in using Shopee online store showed that that trust variable significantly influenced consumer loyalty in using Shopee online store. This is indicated from the results of the partial test where the significance value of the t-calculated was smaller than 0.05 . While the second alternative was by comparing t-calculated with t-table where t-calculated of trust variable was 3.123 compared to t-table of 1.968956 so it can be concluded that trust variable significantly influenced consumer loyalty in using Shopee online store. This is in line with a study by Syahrizal and Umi khabibah (2019). Correlation of trust with consumer loyalty in using Shopee online store shows that consumers have a good impression in using Shopee online store both related to price, promotion conducted by Shopee, and services provided so that consumers continue to use Shopee.

\subsubsection{The Influence of Service Quality on Consumer Loyalty}

The results of hypothesis testing of service quality variable on consumer loyalty in using Shopee online store showed that that service quality variable significantly influenced consumer loyalty in using Shopee online store. This is indicated from the results of the partial test where the significance value of the t-calculated of 0.03 was smaller than 0.05 . Service Quality provided by Shopee is demonstrated through payment process options that do not confuse consumers. At Shopee, the payment process has been simplified. Novice consumers will be very easy to understand. Shopee provides an easy and hassle-free online shopping experience. Because the steps and things that are trending, such as makeup, fashion, etc. can be found easily in Shopee.

\section{Conclusion}

Based on the results and discussion, it can be concluded that : 
a) Based on the results of partial test, service quality significantly influenced Consumer Loyalty in using Shopee online store. Price, Promotion, Trust, and Service Quality can be used as indicators that must be considered by Shopee management in determining Consumer Loyalty in using Shopee online store.

b) Price, Promotion, Trust, and Service Quality can be used as indicators that must be considered by Shopee management in determining Consumer Loyalty in using Shopee online store.

\section{Suggestion}

Based on the conclusion, the authors suggest several things namely :

a) This study will provide maximum results by considering factors other than Price, Promotion, Trust, and Service Quality so that it gives more representative description of the variables to be studied such as product quality, marketing strategies, and so on.

b) In the next study, increase the number of samples not only among students but more generally in order to provide a clearer description of the variables to be studied.

c) In subsequent studies, it is highly recommended to be more careful in respondent data in order to expand the study results obtained.

\section{References}

[1] Buchari Alma,. 2005. Marketing Management and Marketing Services. Bandung: CV Alfabeta.

[2] Kotler, Philip And Kevin Lane Keller. 2009. Marketing Management. Issue 13. Vol.1. Erlangga: Jakarta

[3] Leeraphong, A. and Mardjo, A. (2013). Trust and Risk in Purchase Intention through Online Social Network: A Focus Group Study of Facebook in Thailand. Journal of Economics, Business and Management, 1(4), 314-318.

[4] Philip Kotler. 2005. Marketing Management, Vol. I and II. PT. Index. Jakarta.

[5] Raharja, and Sari, M.P. 2008. Comparison of Analysis Tools (Discriminant and Logistic Regression Against Bond Rating (PT Pefindo). Jurnal Maksi, 8 (1): 87-104.

[6] Syahrizal and Khabibah. 2019. Analysis of the Effect of Ease and Trust in the Use of ECommerce Stores on Consumer Loyalty. Journal of Business Applications, Volume 5 No. 1, ISSN 2407-3741, 163.

[7] Sugiyono, 2007, Business Research Methodology, PT. Gramedia, Jakarta.

[8] Sugiyono. (2014). Educational Research Methods Quantitative, Qualitative, and R\&D Approaches. Bandung: Alfabeta.

[9] Tjiptono, Fandy, 2008, Marketing Strategy, Issue 3, ANDI: Yogyakarta.

[10] Tjiptono, Fandy. 2010, Marketing Strategy, Issue 2, Andi Offset, Yogyakarta. 